Etihad: Journal of Islamic Banking and Finance

Vol. 1, No. 2 Juli-Desember 2021: 98-114

\title{
DETERMINASI PEMBIAYAAN BERMASALAH DI BTN SYARIAH KCS BEKASI PADA MASA PANDEMI
}

\author{
Velia Dwi Yulianti ${ }^{1 *}$, Trisiladi Supriyanto², Mira Rahmi ${ }^{3}$ \\ 1,2,3 Universitas Pembangunan Nasional Veteran Jakarta, Indonesia \\ Email : velia.dwi@upnvj.ac.id, trisiladi.supriyanto@gmail.com,mirarahmi@upnvj.ac.id
}

\begin{abstract}
The covid-19 pandemic has an impact on the community on their income, this affects people who have financing in banks where there are obstacles in paying their installments. This study aims to analyze and prove the effect of monitoring financing, business conditions, customer character, guarantees, and the covid-19 pandemic on nonperforming financing at BTN Syariah KCS Bekasi. The population of this study is customers who have problematic financing at BTN Syariah KCS Bekasi. The sampling technique in this study is the Simple Random Sampling method. In this study, the source of the data obtained was the distribution of questionnaires by obtaining 127 respondents. The data analysis technique used is the SmartPLS 3.0 tool. The results obtained from this study are Financing Monitoring has a significant effect on non-performing financing, Business Conditions has no significant effect on non-performing financing, Customer Character has no significant effect on non-performing financing, Guarantee has no significant effect on non-performing financing, and the Covid-19 pandemic had a significant effect on non-performing financing.
\end{abstract}

Keywords: External Factors, Internal Factors, Covid-19 Pandemi, Non Performing Financing

\begin{abstract}
Abstrak: Pandemi covid-19 memberi dampak pendapatan kepada masyarakat. Hal ini yang memberi pengaruh pada kepemilikan pembiayaan di perbankan berupa kendala angsuran pembayaran. Penelitian ini bertujuan untuk menganalisis serta membuktikan pengaruh pemantauan pembiayaan, kondisi usaha, karakter nasabah, jaminan, dan pandemi covid-19 terhadap pembiayaan bermasalah di BTN Syariah KCS Bekasi. Populasi penelitian yaitu nasabah yang memiliki pembiayaan bermasalah di BTN Syariah KCS Bekasi. Teknik pengumpulan sampel dengan metode Simple Random Sampling. Adapun sumber data yang didapatkan dengan penyebaran kuesioner memperoleh 127 responden. Teknik analisis data yang digunakan dengan alat SmartPLS 3.0. Hasil penelitian menunjukkan bahwa pemantauan pembiayaan berpengaruh signifikan terhadap pembiayaan bermasalah, kondisi usaha tidak berpengaruh signifikan terhadap pembiayaan bermasalah, karakter nasabah tidak berpengaruh signifikan terhadap pembiayaan bermasalah, jaminan tidak berpengaruh signifikan terhadap pembiayaan bermasalah, dan pandemi Covid-19 berpengaruh signifikan terhadap pembiayaan bermasalah.
\end{abstract}

Kata Kunci: Faktor Eksternal, Faktor Internal, Pandemi Covid-19, Pembiayaan Bermasalah. 
Etihad: Journal of Islamic Banking and Finance

Vol. 1, No. 2 Juli-Desember 2021: 98-114

\section{PENDAHULUAN}

Virus covid-19 berawal dari kota Wuhan China pada akhir tahun 2019. Dengan adanya virus covid-19, lebih dari dua ratus negara telah melaporkan, bahwa virus tersebut memasuki negara mereka dan menjadi berita nasional. Virus covid-19 sudah tersebar ke berbagai macam negara salah satunya adalah Indonesia (Niken Widya Yunita, 2020). Salah satu dampak dari virus covid-19 adalah kebijakan social distancing yang disinyalir dapat menyelamatkan nyawa. Namun disisi lain social distancing dapat mengakibatkan kelumpuhan ekonomi sebagai dampaknya ialah jutaan orang mengalami kehilangan pekerjaan atau biasa disebut Pemutus Hubungan Kerja (PHK). Semakin meningkat angka pengangguran, maka dapat memberi dampak pada masa yang akan datang (Jalaludin, 2021). Dampak lain akibat virus ini ialah keadaan industri jasa keuangan perbankan. Perbankan merupakan istilah lembaga keuangan yang memiliki fungsi mediator antara pemilik dana dengan pihak yang memerlukan dana.

Pandemi covid-19 memberi dampak positif dan negataif pada pembiayaan perbankan. Dampak positif pembiayaan berupa terjadinya kenaikan jumlah nasabah yang mengajukan pembiayaan. Akibat covid-19, masyarakat kesulitan memenuhi kebutuhan primer, sehingga banyak yang membutuhkan dana pembiayaan. Masyarakat yang merasakan dampak pandemi telah banyak kehilangan pekerjaan dan usaha yang tidak berjalan lancar. Adapun dampak negatif dari pandemi covid-19 pada pembiayaan adalah terjadinya keterlambatan pembayaran atau pelunasan yang telah ditentukan dalam jangka jatuh tempo, terlebih bagi mereka yang mengalami penurunan pendapatan karena faktor pandemi covid-19 (Esy Nur Aisyah dan Maharani, 2020).

Pembiayaan adalah pemberian dana kepada nasabah yang membutuhkan guna melakukan perubahan (Firdaus, 2015). Pihak bank perlu memperhatikan prinsip 5C dalam menganalisis sebelum memberikan pembiayaan, yaitu karakter (Character), kemampuan (Capacity), modal (Capital), kondisi usaha (Condition of Economic), serta agunan (Collateral) agar mengurangi risiko pembiayaan bermasalah. Ketika nasabah mengalami kesulitan dalam mengembalikan pinjaman yang diajukan ke bank, maka hal demikian dapat menimbulkan pembiayaan bermasalah (Eprianti, 2019).

Pembiayaan bermasalah di bank syariah tidak dapat dihindari. Pihak bank dapat mempunyai suatu gerakan untuk meminimalisir terjadinya pembiayaan bermasalah seperti restrukturisasi. Terdapat dua hal penyebab terjadinya pembiayaan yang ditinjau dari sisi internal dan sisi eksternal (Auliani \& Syaichu, 2016). Faktor internal terjadi karena pihak bank melakukan human error seperti kesalahan analisis, kurang memahami bisnis nasabah, aspek jaminan tidak lebih diperhitungkan dari sisi marketing, serta adanya kelemahan pada pengecekan kredit nasabah. Sedangkan faktor eksternal berupa permasalah nasabah yang mana melakukannya dengan sengaja seperti perilaku tidak jujur atau dana yang tidak digunakan sebagaimana mestinya. Perilaku tidak sengaja seperti terjadinya bencana alam, PHK, dan usaha yang dijalaninya menurun (Ismail, 2010).

Berikut adalah data laporan perkembangan pembiayaan di masa pandemi tahun 2020. 
Etihad: Journal of Islamic Banking and Finance

Vol. 1, No. 2 Juli-Desember 2021: 98-114

Tabel 1. Laporan Aktiva Produktif Berdasarkan Kualitas Bank Umum Syariah dan Unit Usaha Syariah Per-31 Desember 2020

\begin{tabular}{lcccccccccc}
\hline \multicolumn{1}{l}{ Indikator } & Mar & April & Mei & Juni & Juli & Ags & Sep & Okt & Nov & Des \\
\hline $\begin{array}{l}\text { Kurang } \\
\text { Lancar }\end{array}$ & 3.152 & 3.178 & 3.383 & 3.554 & 3.228 & 2.894 & 2.754 & 2.627 & 2.868 & 3.027 \\
Diragukan & 1.976 & 1.773 & 1.565 & 1.713 & 1.771 & 1.737 & 1.741 & 1.525 & 1.375 & 1.382 \\
Macet & 6.941 & 6.941 & 7.113 & 7.132 & 7.358 & 7.598 & 7.659 & 7.780 & 7.902 & 7.800 \\
\hline $\begin{array}{l}\text { Rasio Aset } \\
\text { Non Lancar }\end{array}$ & 2,2 & 2,2 & 2,21 & 2,49 & 2,5 & 2,43 & 2,32 & 2,24 & 2,24 & 2,22 \\
\hline
\end{tabular}

Sumber: OJK, 2020 (data diolah)

Berdasarkan perolehan data yang tertera pada tabel 1, terdapat indikator kurang lancar pada pembiayaan. Pembiayaan mengalami penunggakan pengembalian pinjaman selama 90 sampai dengan 180 hari, yang mana pada bulan Maret hingga Juni mengalami kenaikan, sedangkan pada bulan Juli hingga Desember fluktuatif mengalami kenaikan dan penurunan. Selanjutnya pada indikator diragukan dapat menimbulkan penunggakan pembiayaan selama $181 \mathrm{~s} / \mathrm{d} 360$ hari terhitung mulai bulan Maret hingga Desember yang mengalami kenaikan serta penurunan. Terakhir pada indikator macet, yang mengalami penunggakan pembayaran pinjaman dengan waktu melebihi 360 hari dari jatuh tempo yang sudah ditentukan, serta mengalami kenaikan dan penurunan di setiap bulannya.

Tabel 2. PT Bank Tabungan Negara (Persero) Tbk. Catatan Atas Laporan Keuangan 31 Desember 2020 dan 31 Desember 2019

\begin{tabular}{lrrrr}
\hline & $\begin{array}{c}\text { Nilai } \\
\text { Tercatat }\end{array}$ & $\begin{array}{c}\text { Cadangan } \\
\text { Kerugian } \\
\text { Penurunan }\end{array}$ & Nilai & $\begin{array}{c}\text { Cadangan } \\
\text { Kerugian }\end{array}$ \\
Indikator & $(2020)$ & $(2020)$ & $\begin{array}{c}\text { (2019) } \\
\text { Penurunan }\end{array}$ & (2019) \\
\hline Kurang & 210.625 & 37.079 & 519.838 & 31.293 \\
Lancar & 281.887 & 44.466 & 172.291 & 11.876 \\
Diragukan & 1.143 .912 & 403.710 & 1.092 .205 & 457.731 \\
Macet & 1.636 .424 & 485.255 & 1.784 .334 & 500.900 \\
Total & & & & \\
\hline \multicolumn{4}{l}{ Sumber: PT Bank Tabungan Negara (Persero), 2020 (data diolah). }
\end{tabular}

Data demikian menjelaskan betapa bank BTN Syariah dapat dinyatakan mengikuti aturan yang sudah tertera pada POJK no 11 tahun 2020 mengenai kebijakan yang diberikan 
Etihad: Journal of Islamic Banking and Finance

Vol. 1, No. 2 Juli-Desember 2021: 98-114

dalam penyebaran Coronavirus Disease 2019. Aturan yang diterapkan berupa restrukturisasi kredit atau pembiayaan sebagaimana tertera pada ayat (1) dapat diterapkan terhadap kredit atau pembiayaan yang disalurkan sebelum maupun setelah nasabah merasakan dampak penyebaran virus Covid-19 pada usaha mikro, kecil, dan menengah. Sehingga pada tabel tersebut dapat dilihat perbandingan antara tahun 2019 dengan tahun 2020. Kesimpulan daripada data menjelaskan terjadinya perbandingan demikian karena pada tahun 2020 bank BTN menerapkan sistem perbaikan yaitu restrukturisasi, sehingga dapat menahan angka indikator lancar, pengawasan khusus, kurang lancar, diragukan, dan macet.

Data yang digunakan pada penelitian ini berupa data primer yang bersumber dari hasil penyebaran kuesioner pada nasabah yang memiliki pembiayaan bermasalah di BTN Syariah KCS Bekasi. Penelitian ini menggunakan metode kuantitatif dengan teknik analisis data Partial Least Square (PLS). Dalam Partial Least Square (PLS), terdapat beberapa uji guna memperoleh hasil diantaranya yaitu uji validitas konvergen, uji validitas diskriminan, uji reliabilitas, uji Rsquare, dan uji hipotesis. Dengan demikian, peneliti ingin melakukan penelitian atas faktorfaktor yang memberi pengaruh pada naik turunnya rasio pembiayaan bermasalah di BTN Syariah KCS Bekasi. Adapun rumusan penelitian yang dirumuskan ialah; bagaimanak pengaruh pemantauan pembiayaan, kondisi usaha, karakter nasabah, jaminan, dan pandemi covid-19 terhadap pembiayaan bermasalah di BTN Syariah KCS Bekasi?. Sedangkan tujuan penelitian ini adalah menganalisis dan membuktikan pengaruh pemantauan pembiayaan, kondisi usaha, karakter nasabah, jaminan, dan pandemi covid-19 terhadap pembiayaan bermasalah di BTN Syariah KCS Bekasi.

\section{TINJAUAN LITERATUR}

\section{Pemantauan Pembiayaan}

Menurut Tjoekam 1999 dalam (Saraswati, 2012), pengawasan kredit atau pemantauan pembiayaan dalam perbankan syariah sangat baik untuk dijalankan dengan menerapkan sistem peringatan kecil yang dapat mencegah tanda-tanda penyimpangan dari syarat persetujuan antar pihak bank dengan debitur. Perihal ini yang menyebabkan turunnya mutu pembiayaan atau kredit, serta dapat menentukan kolektibilitas pembiayaan atau kredit.

Menurut (Ikatan Bankir Indonesia, 2015) pemantauan pembiayaan adalah suatu kegiatan bank untuk mengetahui dan memantau perkembangan suatu pemberian pembiayaan, perjalanan suatu pembiayaan, serta perkembangan suatu usaha dimulai dari awal diberikan hingga penyelesaian pembiayaan. Pemantauan pembiayaan kepada nasabah dapat dilakukan dengan:

1. Pemantauan pembiayaan yang dilakukan secara on desk, merupakan pemantauan bank yang dijalankan melalui:

a. Verifikasi data pembiayaan nasabah, apakah ada atau tidaknya riwayat penundaan atas pemenuhan persyaratan pembiayaan.

b. Penelitian dan verifikasi kekurangan yang telah ditemukan.

c. Identifikasi masalah potensial atas pengadaan suatu kas. 
Etihad: Journal of Islamic Banking and Finance

Vol. 1, No. 2 Juli-Desember 2021: 98-114

d. Deteksi kecenderungan menurunnya kondisi keuangan nasabah.

e. Penilaian nasabah dalam memenuhi kewajibannya.

2. Pemantauan pembiayaan yang dijalankan secara out site, yaitu:

a. Kunjungan Lokasi Fisik

Dilakukan untuk melihat situasi di lapangan yang terdiri dari aspek usaha, wujud jaminan, dan mendeteksi permasalahan yang terjadi dalam melakukan usahanya. Kunjungan lokasi juga dilakukan untuk memperkuat pemantauan pembiayaan.

b. Trade Checking

Trade Checking dilaksanakan untuk melihat situasi usaha nasabah yang diberikan pembiayaan dengan memanfaatkannya sumber informasi dari pemasok (supplier).

c. Credit Checking

Pemantauan pembiayaan yang dilakukan dengan memanfaatkan sumber informasi mengenai kelancaran utang piutang nasabah, baik pembiayaan yang disalurkan oleh bank maupun pihak lain.

\section{Kondisi Usaha}

Kondisi usaha yaitu kegiatan bank dalam melaksanakan penilaian peluang usaha calon nasabah (Guntara \& Griadhi, 2019). Menurut (Monulandi et al., 2016) Kondisi Usaha ditinjau dari keadaan ekonomi saat ini hingga keadaan di masa depan yang dihubungkan melalui prospek usaha serta tingkat penjualan. Adapun keadaan ekonomi dapat memberikan pengaruh pada kemampuan nasabah untuk membayar kewajiban. Dalam kondisi ini terbagi menjadi tiga, diantaranya:

1. Lokasi tempat usaha, dilihat dari letak lokasi usaha yang tempatnya strategis dan tidak di area yang memungkinkan terjadi bencana.

2. Ketepatan usaha nasabah, dilihat dari usaha yang sering dicari oleh masyarakat banyak.

3. Usaha yang diterima oleh masyarakat setempat, dilihat dari usaha yang dimiliki nasabah tersebut diterima oleh masyarakat dan memiliki pangsa pasar yang baik.

Menurut Kasmir 2001 dalam (Pandi Afandi, 2010) kondisi usaha memiliki tujuan mengetahui peluang usaha nasabah kedepannya. Dalam penilaian kondisi usaha ini, maka diperlukan pengamatan yang baik seperti kondisi ekonomi saat ini dan masa mendatang berdasarkan bidangnya masing-masing.

\section{Karakter Nasabah}

Karakter nasabah merupakan penilaian yang dilakukan bank terhadap karakter calon nasabah, sehingga pihak bank dapat mengambil kesimpulan bahwa calon nasabah dapat memiliki iktikad baik, jujur, dan tidak menyusahkan bank di masa yang akan datang (Eprianti, 2019). Secara ringkas adalah, karakter merupakan sifat nasabah sebagai penerima pembiayaan (llyas, 2015).

Karakter nasabah merupakan salah satu prinsip yang harus diamati dengan baik. Hal ini dikarenakan kepercayaan atas pemberi pinjaman kepada peminjam haruslah pihak yang memiliki iktikad baik dan dapat dipercaya. Terdapat beberapa hal yang harus dianalisis terlebih dahulu dalam memahami karakter nasabah (Saraswati, 2012), yaitu: 
Etihad: Journal of Islamic Banking and Finance

Vol. 1, No. 2 Juli-Desember 2021: 98-114

1. Riwayat peminjam

2. Kualitas dalam bisnis dan perekonomiannya

3. Manajemen usaha

4. Legalitas usaha

Jaminan

Jaminan dalam bentuk harta benda atas kepemilikan nasabah atau pihak yang bersangkutan yang memberikan jaminannya untuk dijadikan sebagai agunan. Jaminan ini dibentuk dengan tujuan sebagai pertimbangan pihak bank dalam memberikan pembiayaan atau kredit, serta menjadi instrumen opsional atas pembiayaan atau kredit yang diberikan (Nursyahriana et al., 2017). Jaminan merupakan suatu agunan yang dapat memberi keyakinan atau kepercayaan kepada pihak bank, bahwa nasabah dengan usahanya atau dengan pendapatannya secara tetap atau tidak, msks tetap dapat memenuhi kewajibannya (Ulfa, 2017). Jaminan yang diberikan harus memiliki nilai yang lebih besar dibandingkan dengan kreditnya. Jaminan harus benar-benar dimiliki oleh nasabah, dalam arti mempunyai bukti kepemilikan yang akurat dan tidak dalam keadaan sengketa (Anggriawan et al., 2017).

\section{Pembiayaan Bermasalah}

Pembiayaan bermasalah dapat diartikan sebagai risiko pembiayaan yang tidak dapat dihindari. Risiko demikian seperti kondisi pembiayaan yang tidak dapat dikembalikan sesuai tanggal jatuh temponya (Sudarto, 2020). Pembiayaan bermasalah adalah pembiayaan yang dalam pembayarannya memiliki keterlambatan selama 90 hari setelah tanggal penentuannya dan secara luas pembiayaan yang dalam angsurannya mengalami kesulitan, sehingga tidak memenuhi kewajiban minimal yang telah ditentukan hingga pembiayaan yang sulit untuk dilunasi (Juliana \& Ade Sofyan Mulazid, 2017). Menurut Siamat, 2004 dalam (Afif \& Mawardi, 2015) yang menyebabkan terjadinya pembiayaan bermasalah ialah dua faktor, yaitu faktor internal (pihak bank) serta faktor eksternal (pihak nasabah). Pembiayaan bermasalah juga dapat dilihat dari kolektibilitas yang menjadi gambaran situasi pembayaran angsuran dan telah ditentukan pada kesempatan pembiayaan yang disalurkan.

Menurut Siamat 2005 dalam (Festiani, 2018) Rasio Non Performing Finance (NPF) atau pembiayaan bermasalah digunakan untuk menilai suatu kualitaset. Penilaian suatu aset produktif yaitu menilai berbagai jenis aktiva pada suatu bank agar sesuai dengan ketentuan Bank Indonesia. Penilaian ini diharpkan menjadi peluang diterimanya kembali atas dana yang disalurkan pada investasi maupun pembiayaan yang diketahui. Adapun terlaksananya kegiatan bank dapat berhubungan dengan aset produktif yang dimiliki. Dengan demikian pihak bank dituntut untuk melakukan manajemen dengan baik agar dapat memantau serta menganalisis kualitas aset yang dimiliki.

\section{Pandemi Covid-19}

Seperti yang telah dikemukakan oleh Syukra dan Ridha 2020 dalam (Sumadi, 2020) virus covid-19 pada bulan maret 2020 mulai memasuki Indonesia hingga saat ini dan penularannya terus meningkat. Pemerintah melakukan berbagai macam upaya untuk menstabilkan perekonomian. Langkah awal mengendalikan virus ini adalah dengan 
Etihad: Journal of Islamic Banking and Finance

Vol. 1, No. 2 Juli-Desember 2021: 98-114

diberlakukannya lock down dan PSBB. Banyak komentar yang diterima pemerintah untuk segera mengambil upaya preventif lockdown guna memberikan perlindungan kepada masyarakat dan tenaga medis. Penerapan lock down atau Pembatasan Sosial Berskala Besar (PSBB) merupakan cara yang paling tepat untuk menahan penyebaran virus. Pemerintah menganjurkan kepada masyarakat untuk menerapkan pembatasan dalam berbagai kegiatan. Anjuran ini memasuki sektor-sektor tertentu, serta menganjurkan mengganti jadwal aktivitas yang sekiranya bersifat mengumpulkan banyak orang, sehingga anjuran presiden untuk belajar di rumah, bekerja di rumah, serta beribadah di rumah sudah diterapkan (Thorik, 2020).

Salah satu dampak covid-19 adalah diberlakukannya social distancing. Social distancing disinyalir dapat menyelamatkan nyawa manusia, namun di sisi lain dapat mengakibatkan terjadinya kelumpuhan ekonomi dan kehilangan pekerjaan atau Pemutusan Hubungan Kerja (PHK). Didapati sejumlah 31.444 perusahaan yang memutuskan untuk melakukan PHK kepada karyawannya. Dari data tersebut, sekitar 538.385 dari 2.084 .593 karyawan telah mengalami Pemutusan Hubungan Kerja (PHK). Jumlah demikian dapat dikatakan cukup banyak. Jika terus terjadi, maka dapat memberi dampak yang memprihatinkan di masa mendatang (Jalaludin, 2021).

Tantangan utama yang dihadapi pada pandemi covid-19 adalah pembiayaan. Pembiayaan dapat terjadi karena pihak bank belum dapat menjalankan ekspansi ketepatan pada turunnya suatu permintaan, sehingga bank lebih berfokus pada implementasi kebijakan restrukturisasi pembiayaan yang disalurkan kepada nasabah. Oleh karena itu, bank syariah harus tetap selektif dalam menyalurkan dana di tengah pandemi covid-19, sehingga dapat menjaga rasio pembiayaan bermasalah. Dengan segala keterbatasan kegiatan selama pandemi terjadi, maka dapat mempengaruhi pembiayaan perbankan. Selain mempengaruhi sisi penyaluran dana, juga mempengaruhi risiko pembiayaan bermasalah. Hal demikian dapat menentukan bertahan atau bangkitnya suatu bank. Risiko demikian muncul karena adanya pembatasan aktivitas selaku upaya pemerintah untuk meminimalisir penyebaran covid-19. Dengan adanya pembatasan aktivitas dan ekonomi, maka mengakibatkan turunnya suatu kegiatan. Demikian telah dihadapi oleh perbankan syariah dan perbankan konvensional. Risiko yang terjadi yaitu kesulitan likuiditas, penurunan aset keuangan serta profitabilitas (Sumadi, 2020).

\section{METODE PENELITIAN}

Penelitian ini ialah penelitian kuantitatif. Nasabah yang mengalami pembiayaan bermasalah di BTN Syariah KCS Bekasi merupakan populasi yang terdapat dalam penelitian ini. Metode yang diterapkan adalah Probablitity Sampling, yaitu Simple Random Sampling. Untuk menentukan ukuran suatu sampel, maka digunakan rumus slovin dengan memperoleh angka minimal 100 responden. Penelitian ini memperoleh 127 responden. Adapun metode pengambilan dan pengumpulan data ialah kuesioner. Partial Least Square (PLS) merupakan instrumen yang digunakan untuk teknik analisis penelitian. Terdapat beberapa variabel yang digunakan dalam penelitian ini; Pembiayaan Bermasalah sebagai variabel $(\mathrm{Y})$ atau biasa 
Etihad: Journal of Islamic Banking and Finance

Vol. 1, No. 2 Juli-Desember 2021: 98-114

disebut variabel terikat. Kemudian variabel bebasnya yaitu Pemantauan Pembiayaan (X1), Kondisi Usaha (X2), Karakter Nasabah (X3), Jaminan (X4), dan Pandemi Covid-19 (X5).

\section{HASIL DAN PEMBAHASAN}

\section{Uji Hipotesis dan Analisis}

Terdapat beberapa analisis data yang dilakukan pada penelitian ini diantaranya uji validitas, uji reliabilitas, dan uji R-Square. Analisis data selanjutnya menggunakan uji tstatistik sebagai bentuk pengujian hipotesis. Seluruh uji tersebut dilakukan dengan alat Partial Least Square (PLS).

\section{Model Pengukuran (Outer Model)}

Nilai yang harus dipenuhi dalam uji Convergent Validity adalah nilai loading factor yang harus di atas 0,70. Kemudian untuk nilai loading factor 0,5 hingga 0,6 masih dikatakan cukup untuk memenuhi persyaratan dan dapat dikatakan bahwa indikator yang digunakan sudah cukup valid (Slamet Riyanto \& Aglis Andhita Hatmawan, 2020).

Tabel 3. Uji Validitas Konvergen

\begin{tabular}{|c|c|c|c|c|c|c|}
\hline & $\begin{array}{l}\text { Pem. } \\
\text { Pembiayaan }\end{array}$ & $\begin{array}{l}\text { Kondisi } \\
\text { Usaha }\end{array}$ & $\begin{array}{l}\text { Karakter } \\
\text { Nasabah }\end{array}$ & Jaminan & $\begin{array}{l}\text { Pandemi } \\
\text { Covid-19 }\end{array}$ & $\begin{array}{l}\text { Pemb. } \\
\text { Bermasalah }\end{array}$ \\
\hline X1.1 & 0.642 & & & & & \\
\hline $\mathrm{X} 1.2$ & 0.825 & & & & & \\
\hline$X 1.3$ & 0.635 & & & & & \\
\hline X1.4 & 0.675 & & & & & \\
\hline$X 1.5$ & 0.603 & & & & & \\
\hline X1.6 & 0.543 & & & & & \\
\hline$X 2.1$ & & 0.867 & & & & \\
\hline$X 2.2$ & & 0.638 & & & & \\
\hline$X 2.3$ & & 0.761 & & & & \\
\hline$X 2.4$ & & 0.285 & & & & \\
\hline$X 2.5$ & & 0.727 & & & & \\
\hline X3.1 & & & 0.766 & & & \\
\hline X3.2 & & & 0.788 & & & \\
\hline X3.3 & & & 0.801 & & & \\
\hline X3.4 & & & 0.222 & & & \\
\hline X3.5 & & & 0.837 & & & \\
\hline X3.6 & & & 0.750 & & & \\
\hline$X 4.1$ & & & & 0.770 & & \\
\hline$X 4.2$ & & & & 0.793 & & \\
\hline$X 4.3$ & & & & 0.750 & & \\
\hline$X 4.4$ & & & & 0.843 & & \\
\hline$X 4.5$ & & & & 0.861 & & \\
\hline
\end{tabular}


Etihad: Journal of Islamic Banking and Finance

Vol. 1, No. 2 Juli-Desember 2021: 98-114

\begin{tabular}{lll}
\hline $\mathrm{X} 5.1$ & 0.874 & \\
\hline $\mathrm{X} 5.2$ & 0.857 & \\
\hline $\mathrm{X} 5.3$ & 0.793 & \\
\hline $\mathrm{X} 5.4$ & 0.852 & \\
\hline $\mathrm{Y} 1.1$ & & 0.761 \\
\hline $\mathrm{Y} 1.2$ & & 0.581 \\
\hline $\mathrm{Y} 1.3$ & & 0.438 \\
\hline $\mathrm{Y} 1.4$ & & 0.817 \\
\hline $\mathrm{Y} 1.5$ & & 0.565 \\
\hline
\end{tabular}

Sumber: Hasil Output Smart PLS

Berdasarkan tabel tersebut, dapat dikatakan bahwa mayoritas nilai dari pertanyaan di atas 0.50 ,a. Namun didapati beberapa pertanyaan yang masih memiliki nilai di bawah 0.50 . Hal ini dapat disimpulkan bahwa pertanyaan yang memiliki nilai dibawah 0.50 harus dihapuskan. Demikian karena nilai yang di bawah 0.50 dianggap belum valid atau belum mencukupi nilai syarat pada validitas konvergen.

Tabel 4. Uji Validitas dan Reliabilitas

\begin{tabular}{cccc}
\hline Variabel & AVE & $\begin{array}{c}\text { Composite } \\
\text { Reliability }\end{array}$ & $\begin{array}{c}\text { Cronbach } \\
\text { Alpha }\end{array}$ \\
\hline Pemantauan Pembiayaan & 0.520 & 0.811 & 0.691 \\
Kondisi Usaha & 0.588 & 0.849 & 0.770 \\
Karakter Nasabah & 0.525 & 0.858 & 0.801 \\
Jaminan & 0.646 & 0.901 & 0.863 \\
Pandemi Covid-19 & 0.713 & 0.909 & 0.866 \\
Pembiayaan Bermasalah & 0.562 & 0.788 & 0.597 \\
\hline
\end{tabular}

Sumber: Data diolah

Uji validitas diskriminan demikian dilakukan untuk menilai suatu validitas konstruk dengan melihat nilai yang ada pada Average Variance Extracted (AVE) di atas 0.50 pada setiap konstruknyaa. Apabila nilai tersebut sudah di atas 0.50 , maka dapat dinyatakan variabel yang digunakan sudah valid (Ghazali \& Hengky Latan, 2015). Berdasarkan hasil olahan data di atas, hasil nilai Average Variance Extracted (AVE) sudah di atas 0.50 , sehingga disimpulkan bahwa variabel Pemantauan Pembiayaan, Kondisi Usaha, Karakter Nasabah, Jaminan, Pandemi Covid-19, dan Pembiayaan Bermasalah memiliki nilai di atas 0.50 , yang artinya seluruh data variabel sudah valid.

Pada tabel tersebut dapat dikatakan bahwa nilai yang terdapat pada Composite Reliability ialah seluruh variabel lebih dari 0.70 , yang mana hal tersebut menunjukkan semua variabel pada uji ini telah memenuhi persyaratan. Dari nilai tersebut, maka dapat dinyatakan bahwa nilai Composite Reliability dikatakan baik pada masing-masing konstruk. 
Etihad: Journal of Islamic Banking and Finance

Vol. 1, No. 2 Juli-Desember 2021: 98-114

Pada tabel tersebut dapat dikatakan juga bahwa nilai yang terdapat pada Cronbach Apha pada seluruh variabelnya lebih dari 0.50. Nilai tersebut dapat dikatakan sudah reliable (Imam Ghozali, 2018).

\section{Model Struktural (Inner Model)}

Uji $R$-Square dilakukan untuk melihat adanya kemampuan pada model dalam menjelaskan hasil dari variabel dependen tersebut. Uji $R$-Square dalam penelitian ini adalah:

Tabel. R-Square

\begin{tabular}{lc}
\hline & R-Square \\
\hline Pembiayaan Bermasalah & 0.544 \\
\hline & Sumber: Data diolah
\end{tabular}

Terlihat pada tabel di atas, bahwa variabel pembiayaan bermasalah menunjukkan hasilnya sebesar 0.544 , sehingga dapat dinyatakan bahwa variabel independen yang terdiri dari pemantauan pembiayaan, kondisi usaha, karakter nasabah, jaminan, serta pandemi covid-19 mampu memberikan penjelasan pada variabel dependen yaitu pembiayaan bermasalah sebesar $54.4 \%$, yang mana sisanya $45.6 \%$ diterangkan dari faktor lain di luar penelitian ini.

Pada uji Q-Square memiliki tujuan untuk mengetahui seberapa baik nilai observasi yang didapatkan dalam model. Untuk mengetahuinya terdapat perhitungan Q-square dengan rumus:

$$
Q^{2}=1-\left(1-R_{1}{ }^{2}\right)
$$

$\mathrm{R}_{1}{ }^{2}$ merupakan $R$-Square variabel endogen yang ada pada model penelitian. Nilai besaran $Q$-Square yaitu rentang $0<Q^{2}<1$, dimana jika semakin mendekati 1 , maka model penelitian dikatakan baik.

$$
\begin{aligned}
Q^{2}= & 1-(1-0.544) \\
& =0.544
\end{aligned}
$$

Hasil perhitungan Q-Square menunjukkan angka sebesar 0.544 , dimana hal tersebut sesuai dengan ketentuan $0<0.544<1$ yang berarti semakin mendekati model dan dikatakan baik.

\section{Uji Hipotesis}

Hasil perolehan dari uji hipotesis dalam penelitian ini dapat dilihat pada tabel dibawah ini:

Tabel 5. Uji T-Statistik

\begin{tabular}{lccc}
\hline & $\begin{array}{c}\text { Original } \\
\text { Sampel (O) }\end{array}$ & T-Statistics & $P$ Value \\
\hline Pemantauan & 0.258 & 3.042 & 0.002 \\
Pembiayaan terhadap & & &
\end{tabular}


Etihad: Journal of Islamic Banking and Finance

Vol. 1, No. 2 Juli-Desember 2021: 98-114

\begin{tabular}{llll}
\hline $\begin{array}{l}\text { pembiayaan } \\
\text { bermasalah }\end{array}$ & & & \\
$\begin{array}{l}\text { Kondisi usaha } \\
\text { terhadap pembiayaan }\end{array}$ & -0.059 & 0.592 & 0.554 \\
bermasalah & & & \\
Karakter nasabah & 0.044 & 0.470 & 0.639 \\
terhadap pembiayaan & & & \\
bermasalah & & \\
$\begin{array}{l}\text { Jaminan terhadap } \\
\text { pembiayaan } \\
\text { bermasalah } \\
\begin{array}{l}\text { Pandemi covid-19 } \\
\text { terhadap pembiayaan } \\
\text { bermasalah }\end{array}\end{array}$ \\
\hline
\end{tabular}

Sumber: Data diolah

Berdasarkan tabel tersebut, maka hasil pengolahan uji t-statistik menyimpulkan, bahwa pemantauan pembiayaan terhadap pembiayaan bermasalah senilai thitung sebesar 3.042, kemudian $t_{\text {tabel }}$ sebesar 1.98. Dari hasil ini dapat disimpulkan bahwa $t_{\text {hitung }}>t_{\text {tabel. }}$. Kemudian pada tingkat signifikansi variabel pemantauan pembiayaan memiliki nilai 0.002 , dimana lebih kecil dari nilai signifikansi yaitu 0.05 (0.002<0.05), sehingga dapat disimpulkan bahwa $\mathrm{H}_{\mathrm{a}}$ diterima dan $\mathrm{H}_{\mathrm{o}}$ ditolak. Dapat dikatakan juga bahwa pemantauan pembiayaan memiliki signifikansi pengaruh atas pembiayaan bermasalah.

Hasil pengolahan uji t-statistik menunjukkan bahwa kondisi usaha terhadap pembiayaan bermasalah senilai $t_{\text {hitung }}$ sebesar 0.592 kemudian $t_{\text {tabel }}$ sebesar 1.98 , sehingga dapat disimpulkan bahwa $t_{\text {hitung }}>t_{\text {tabel. }}$. Kemudian pada tingkat signifikansi variabel kondisi usaha memiliki nilai 0.554 , dimana lebih besar dari nilai signifikansi yaitu 0.05 (0.554 > 0.05). Dapat dikatakan bahwa $\mathrm{H}_{\mathrm{o}}$ diterima dan $\mathrm{H}_{\mathrm{a}}$ ditolak. Kesimpulannya adalah bahwa kondisi usaha tidak memiliki signifikansi pengaruh atas pembiayaan bermasalah.

Hasil dari pengolahan uji t-statistik menyimpulkan bahwa pada variabel karakter nasabah terhadap pembiayaan bermasalah didapati nilai $t_{\text {hitung }}$ sebesar 0.470 dan $t_{\text {tabel }}$ sebesar 1.98 , sehingga dapat disimpulkan bahwa $t_{\text {hitung }}>t_{\text {tabel }}$. Kemudian pada tingkat signifikansi pada variabel jaminan memiliki nilai 0.639 dimana lebih besar dari nilai signifikansi yaitu $0.05(0.639>0.05)$. Sehingga dapat dikatakan bahwa $\mathrm{H}_{\mathrm{o}}$ diterima dan $\mathrm{H}_{\mathrm{a}}$ ditolak. Kesimpulannya adalah bahwa karakter nasabah tidak memiliki signifikansi pengaruh terhadap pembiayaan bermasalah.

Hasil pengolahan uji t-statistik menyimpulkan bahwa jaminan terhadap pembiayaan bermasalah memiliki nilai $t_{\text {hitung }}$ sebesar $1.790, t_{\text {tabel }}$ sebesar 1.98 dan dapat disimpulkan bahwa $t_{\text {hitung }}>t_{\text {tabel. }}$. Kemudian pada tingkat signifikansi variabel kondisi usaha memiliki nilai 0.074, dimana lebih besar dari nilai signifikansi yaitu 0.05 (0.074>0.05). Maka 
Etihad: Journal of Islamic Banking and Finance

Vol. 1, No. 2 Juli-Desember 2021: 98-114

dapat dikatakan bahwa $\mathrm{H}_{\mathrm{o}}$ diterima dan $\mathrm{H}_{\mathrm{a}}$ ditolakbahwa jaminan tidak terdapat sign. Kesimpulannya adalah didapati signifikansi pengaruh terhadap pembiayaan bermasalah.

Hasil dari pengolahan uji t-statistik menunjukkan bahwa pandemi covid-19 terhadap pembiayaan bermasalah terdapat nilai thitung sebesar 5.310 dan $t_{\text {tabel }}$ sebesar 1.98, sehingga disimpulkan bahwa $t_{\text {hitung }}>t_{\text {tabel }}$. Kemudian pada tingkat signifikansi pada variabel pandemi covid-19 memiliki nilai 0.000, dimana lebih kecil dari nilai signifikansi 0.05 (0.000 $<0.05)$. Kesimpulannya adalah bahwa $\mathrm{H}_{\mathrm{a}}$ diterima dan $\mathrm{H}_{\mathrm{o}}$ ditolak. Pandemi covid-19 memiliki signifikansi pengaruh terhadap pembiayaan bermasalah.

\section{Pembahasan}

Berdasarkan hasil perhitungan penelitian mengenai pemantauan pembiayaan, kondisi usaha, karakter nasabah, jaminan, dan pandemi covid-19 terhadap pembiayaan bermasalah di BTN Syariah KCS Bekasi dengan menggunakan alat analisis SmartPLS 3.0, maka diperoleh hasil sebagai berikut:

\section{Pengaruh Pemantauan Pembiayaan terhadap Pembiayaan Bermasalah}

Berdasarkan hasil proses uji t-statistik pada variabel pemantauan pembiayaan dalam pembiayaan bermasalah, maka menunjukkan bahwa hasil perolehan uji pemantauan pembiayaan memiliki pengaruh signifikan terhadap pembiayaan bermasalah. Pernyataan demikian dapat diterangkan berdasarkan perolehan hasil uji t-statistik yang menjelaskan bahwa pemantauan pembiayaan terhadap pembiayaan bermasalah memiliki nilai thitung $_{\text {. }}$ sebesar 3.042. Sedangkan $t_{\text {tabel }}$ sebesar 1.98, sehingga dapat disimpulkan bahwa $t_{\text {hitung }}>t_{\text {tabel }}$. Kemudian pada tingkat signifikansi variabel pemantauan pembiayaan memiliki nilai 0.002 , dimana lebih rendah dari nilai signifikansi $0.05(0.002<0.05)$. Kesimpulannya adalah bahwa $\mathrm{H}_{\mathrm{a}}$ diterima dan $\mathrm{H}_{\mathrm{o}}$ ditolak. Dikatakan bahwa pemantauan pembiayaan memiliki signifikansi pengaruh terhadap pembiayaan bermasalah.

Oleh sebab itu dapat dikatakan, jika pemantauan pembiayaan yang dilakukan oleh bank berjalan dengan baik, maka tingkat risiko terjadinya pembiayaan bermasalah akan berkurang. Namun jika dalam pemantauan pembiayaan bank berjalan kurang baik, maka dapat menimbulkan risiko terjadinya pembiayaan bermasalah. Pemantauan pembiayaan yang berjalan dengan baik, tersusun, dan terjadwal secara langsung atupun tidak langsung dapat memberi pengaruh pada pengurangan risiko pembiayaan bermasalah. Hasil perolehan ini sesuai dengan penelitian terdahulu yang dilakukan oleh Fatimah dan Desrini Ningsih (2017), bahwa pengawasan kredit berpengaruh terhadap kredit bermasalah.

\section{Pengaruh Kondisi Usaha Terhadap Pembiayaan Bermasalah}

Berdasarkan hasil proses uji t-statistik pada variabel kondisi usaha pada pembiayaan bermasalah, maka menunjukkan hasil perolehan uji bahwa kondisi usaha memiliki pengaruh yang tidak signifikan terhadap pembiayaan bermasalah. Pernyataan ini diterangkan berdasarkan hasil dari uji t-statistik yang menyatakan bahwa kondisi usaha terhadap pembiayaan bermasalah memiliki nilai $t_{\text {hitung }}$ sebesar 0.592 , sedangkan $t_{\text {tabel }}$ sebesar 1.98 , sehingga dapat disimpulkan bahwa $t_{\text {hitung }}>t_{\text {tabel. }}$. Kemudian pada tingkat signifikansi variabel kondisi usaha memiliki nilai 0.554, dimana lebih besar dari nilai signifikansi yaitu 0.05 (0.554 > 
Etihad: Journal of Islamic Banking and Finance

Vol. 1, No. 2 Juli-Desember 2021: 98-114

0.05). Kesimpulannya adalah bahwa $\mathrm{H}_{\mathrm{o}}$ diterima dan $\mathrm{H}_{\mathrm{a}}$ ditolak dan dikatakan kondisi usaha tidak memiliki signifikansi pengaruh terhadap pembiayaan bermasalah.

Kondisi yang dimaksud ialah kondisi usaha yang dijalankan oleh nasabah yang menimbulkan akibat dari suatu kondisi yang kurang menguntungkan, sehingga menyebabkan hilangnya kemampuan nasabah dalam melunasi kewajibannya. Semakin baik kondisi usaha yang dialami nasabah, maka dapat mengurangi risiko pembiayaan bermasalah, dan begitupun sebaliknya. Jika kondisi usaha nasabah kurang baik, maka dapat menimbulkan pembiayaan bermasalah. Seperti presentase NPF di bank BTN Syariah KCS Bekasi yang dinilai persentase sebesar $1.94 \%$ pada tahun 2020 saat terjadinya pandemi covid-19. Peraturan Otoritas Jasa Keuangan tolak ukur tinggi rendah menyatakan persentase NPF itu tidak boleh lebih dari 5\%. Semakin rendah nilai persentase NPF, maka bank semakin baik dalam mengelola pembiayaan. Dalam arti bank dapat menganalisis nasabah pembiayaan yang selanjutnya memiliki kriteria baik dari segi jenis usaha yang dimiliki.

Penelitian ini sesuai dengan penelitian terdahulu yang dilakukan oleh Andi Nursyahriana, Michael Hadjat, Irsan Tricahyadinata (2017) dan Ulfa (2017), terdapat kondisi usaha yang tidak berpengaruh signifikan terhadap kredit bermasalah. Kesimpulannya adalah, walaupun terjadi pandemi covid-19, kondisi usaha tidak memiliki pengaruh terhadap pembiayaan bermasalah. Peran pemantauan pembiayaan dan kebijakan pemerintah mengenai restrukturisasi yang dijalankan oleh bank berjalan dengan baik. Peran ini dapat digunakan pada masa pandemi dengan melihat kondisi usaha, sehingga dapat meminimalisir risiko pembiayaan bermasalah.

\section{Pengaruh Karakter Nasabah Terhadap Pembiayaan Bermasalah}

Berdasarkan hasil proses uji t-statistik variabel karakter nasabah pada pembiayaan bermasalah, maka menunjukkan hasil bahwa kondisi usaha memiliki pengaruh yang tidak signifikan terhadap pembiayaan bermasalah. Hal ini dapat diterangkan sesuai hasil uji $t-$ statistik yang menunjukkan bahwa karakter nasabah terhadap pembiayaan bermasalah memiliki nilai $t_{\text {hitung }}$ sebesar 0.470 , sedangkan $t_{\text {tabel }}$ sebesar 1.98 , sehingga disimpulkan bahwa $t_{\text {hitung }}>t_{\text {tabel. }}$ Kemudian pada tingkat signifikansi pada variabel jaminan memiliki nilai 0.639, dimana lebih besar dari nilai signifikansi yaitu $0.05(0.639>0.05)$. Kesimpulannya adalah bahwa $\mathrm{H}_{\mathrm{o}}$ diterima dan $\mathrm{H}_{\mathrm{a}}$ ditolak. Karakter nasabah tidak memiliki signifikansi pengaruh terhadap pembiayaan bermasalah.

Hal ini dapat dikatakan, jika karakter nasabah semakin baik dalam arti tepat waktu dalam membayar angsuran, beriktikad baik, jujur, dan memiliki perilaku yang baik, maka dapat mengurangi risiko pembiayaan bermasalah. Namun sebaliknya, jika karakter nasabah tidak memiliki iktikad baik, tidak bertanggung jawab, dan tidak tepat waktu dalam membayar angsuran, maka hal tersebut dapat menimbulkan terjadinya pembiayaan bermasalah. Seperti presentase NPF di bank BTN Syariah KCS Bekasi yang didapati nilai persentase sebesar 1.94\% pada tahun 2020. Peraturan Otoritas Jasa Keuangan tolak ukur tinggi rendah menyatakan bahwa persentase NPF itu tidak boleh lebih dari 5\%. Semakin rendah nilai persentase NPF, maka bank semakin baik dalam mengelola pembiayaan. Dalam hal ini dapat disimpulkan 
Etihad: Journal of Islamic Banking and Finance

Vol. 1, No. 2 Juli-Desember 2021: 98-114

bahwa bank BTN Syariah KCS Bekasi telah melakukan analisis pembiayaan yang diberikan kepada nasabah dengan baik, seperti dalam pembinaan nasabah dalam hal penagihan, restrukturisasi, serta penyelesaian pembiayaan yang memberi pengaruh positif terhadap nasabah.

Hasil penelitian ini tentunya tidak sesuai dengan penelitian t Andi Nursyahriana, Michael Hadjat, Irsan Tricahyadinata (2017) dan Ulfa (2017) yang menjelaskan variabel karakter nasabah tidak relevan. Bank BTN Syariah KCS Bekasi pada masa pandemi covid-19 telah menjalani prosedur analisis pemberian pembiayaan secara baik, sehingga nasabah memiliki karakter dan perilaku yang baik. Pemantauan pembiayaan dan kebijakan pemerintah mengenai restrukturisasi dijalankan oleh bank dengan sangat baik.

\section{Pengaruh Jaminan Terhadap Pembiayaan Bermasalah}

Berdasarkan hasil proses uji t-statistik pada variabel jaminan pada pembiayaan bermasalah, menunjukkan bahwa hasil bahwa kondisi usaha memiliki pengaruh yang tidak signifikan terhadap pembiayaan bermasalah. Hal ini dapat diterangkan sesuai hasil uji tstatistik yang menjelaskan bahwa jaminan terhadap pembiayaan bermasalah memiliki nilai $t_{\text {hitung }}$ sebesar 1.790 dan $t_{\text {tabel }}$ sebesar 1.98 , sehingga dapat disimpulkan bahwa $t_{\text {hitung }}>t_{\text {tabel }}$. Kemudian pada tingkat signifikansi pada variabel kondisi usaha memiliki nilai 0.074 , dimana lebih besar dari nilai signifikansi $0.05(0.074>0.05)$. Kesimpulannya adalah bahwa $\mathrm{H}_{\circ}$ diterima dan $\mathrm{H}_{a}$ ditolak. Jaminan tidak memiliki signifikansi pengaruh terhadap pembiayaan bermasalah.

Nasabah yang memiliki kredit mempunyai jaminan dan dapat dimanfaatkan sebagai alat pengaman apabila terdapat ketidakpastian dalam pelunasan pembiayaan. Jaminan demikian dapat disita apabila nasabah benar-benar tidak dapat melunasi kewajibannya. Jaminan sebagai antisipasi seandainya nasabah tidak dapat melunasi biaya yang diwajibkan. Jaminan pada umumnya memiliki nilai yang lebih tinggi dari jumlah pinjaman yang diajukan.

Hasil penelitian ini sesuai dengan penelitian Ulfa (2017) yang menunjukkan bahwa variabel jaminan tidak memiliki pengaruh terhadap kredit macet. Hal ini disebabkan karena jika nasabah tidak mampu lagi dalam membayar angsurannya, maka pihak bank BTN Syariah KCS Bekasi dapat memberi keringanan berupa perbaikan seperti yang telah tertera pada Peraturan Otoritas Jasa Keuangan (POJK). Dianjurkan kepada bank untuk melakukan restrukturisasi, sehingga nasabah tetap dapat mengangsur. Perbedaanya hanyalah pada perpanjangan jangka waktu, sehingga nasabah tidak memberikan jaminan sebagai langkah terakhir untuk menyelesaikan permasalahan pembiayaan.

\section{Pengaruh Pandemi Covid-19 Terhadap Pembiayaan Bermasalah}

Berdasarkan hasil proses uji t-statistik pada variabel Pandemi Covid-19 pada pembiayaan bermasalah, maka menunjukkan hasil kondisi usaha memiliki pengaruh yang signifikan terhadap pembiayaan bermasalah. Hal ini dapat dijelaskan berdasarkan hasil pendapat uji t-statistik yang menunjukkan pembiayaan bermasalah di masa pandemi memiliki nilai $t_{\text {hitung }}$ sebesar 5.310 dan $t_{\text {tabel }}$ sebesar 1.98 , sehingga dapat disimpulkan bahwa $t_{\text {hitung }}>$ $t_{\text {tabel. }}$ Kemudian pada tingkat signifikansi variabel pandemi covid-19 memiliki nilai 0.000 
Etihad: Journal of Islamic Banking and Finance

Vol. 1, No. 2 Juli-Desember 2021: 98-114

dimana lebih rendah dari nilai signifikansi $0.05(0.000<0.05)$. Dikatakan bahwa $\mathrm{H}_{\mathrm{a}}$ diterima dan $\mathrm{H}_{\mathrm{o}}$ ditolak, sehingga dapat disimpulkan ahwa pandemi covid-19 memiliki signifikansi pengaruh terhadap pembiayaan bermasalah.

\section{KESIMPULAN}

Berdasarkan hasil uji T-Statistik yang telah dilakukan, maka diketahui bahwa pemantauan pembiayaan dan pandemi covid-19 memiliki pengaruh signifikan terhadap pembiayaan bermasalah. Akan tetapi pada kondisi usaha, karakter nasabah, dan jaminan tidak memiliki pengaruh signifikan terhadap pembiayaan bermasalah. Pemantauan pembiayaan yang dijalankan oleh bank berjalan dengan baik dapat meminimalisir risiko pembiayaan bermasalah. Pada kondisi usaha, karakter nasabah, dan jaminan dapat dikatakan jika kondisi usaha dan karakter menjadi baik, maka dapat meminimalisir terjadinya pembiayaan bermasalah. Hal demikian karena pemantauan pembiayaan bank serta kebijakan pemerintah atas restrukturisasi berjalan dengan baik, sehingga dapat berpengaruh pada kondisi usaha serta karakter nasabah yang tidak memiliki pengaruh terhadap pembiayaan bermasalah. Dengan pemantauan yang baik, maka jaminan dijadikan sebagai instrumen opsional jika nasabah tidak lagi mampu membayar angsuran. Pandemi Covid-19 telah memberi dampak kepada masyarakat yang berstatus sebagai karyawan atau yang memiliki usaha.

\section{REFERENSI}

Afif, Z. N., \& Mawardi, I. (2015). Pengaruh Pembiayaan Murabahah Terhadap Laba Melalui Variabel Intervening Pembiayaan Bermasalah Bank Umum Syariah di Indonesia Periode 2009-2013. Jurnal Ekonomi Syariah Teori Dan Terapan, 1(8), 565. https://doi.org/10.20473/vol1iss20148pp565-580

Anggriawan, I. G. B. F., Herawati, N. T., \& I Gusti Ayu Purnamawati. (2017). Analisis Prinsip 5C Dan 7P Dalam Pemberian Kredit Untuk Meminimalisir Kredit Bermasalah Dan Meningkatkan Profitabilitas (Studi Kasus Pada Pt. Bpr Pasar Umum Denpasar - Bali). JIMAT (Jurnal IImiah Mahasiswa Akuntansi), 8(2), 12.

Auliani, M. M., \& Syaichu. (2016). Analisis Pengaruh Faktor Internal dan Faktor Eksternal Terhadap Tingkat Pembiayaan Bermasalah Pada Bank Umum Syariah di Indonesia Periode Tahun 2010-2014. Journal Of Economics, 5, 11.

Eprianti, N. (2019). Penerapan Prinsip 5C Terhadap Tingkat Non Performing Financing (Npf). Amwaluna: Jurnal Ekonomi Dan Keuangan Syariah, 3(2). https://doi.org/10.29313/amwaluna.v3i2.4645

Esy Nur Aisyah dan Maharani. (2020). Strategi Penanganan Pembiayaan Bermasalah Pada UMKM di Masa Pandemi Covid. 288.

Festiani, E. R. (2018). Analisis Pengaruh Rasio CAR, NPF, BOPO, ROA dan FDR terhadap tingkat Kesehatan Bank Umum Syariah di Indonesia. El Dinar, 4(2), 196. https://doi.org/10.18860/ed.v4i2.5462 
Etihad: Journal of Islamic Banking and Finance

Vol. 1, No. 2 Juli-Desember 2021: 98-114

Firdaus, R. N. (2015). Pengaruh Faktor Internal dan Eksternal Yang Mempengaruhi Pembiayaan Bermasalah Pada Bank Umum Syariah di Indonesia. 3(1), 82-108.

Ghazali, I., \& Hengky Latan. (2015). Partial Least Squares Konsep, Teknik dan Aplikasi Menggunakan Program SmartPLS 3.0 (Ed.2). Universiras Diponegoro.

Guntara, I. M. A., \& Griadhi, N. M. A. Y. (2019). Penerapan Prinsip 5C Sebagai Upaya Perlindungan Terhadap Bank Dalam Menyalurkan Kredit. Kertha Semaya : Journal IImu Hukum, Vol 7 No 8, 1-15.

Ikatan Bankir Indonesia. (2015). Mengelola Bisnis Pembiayaan Bank Syariah (Edisi Ke-1). PT Gramedia Pustaka Utama.

Ilyas, R. (2015). Konsep Pembiayaan Dalam Perbankan Syari'Ah. Jurnal Penelitian, 9(1), 183204. https://doi.org/10.21043/jupe.v9i1.859

Imam Ghozali. (2018). Aplikasi Analisis Multivariate dengan Program SPSS (Ed.5). Badan Penerbit Universitas Diponegoro.

Ismail. (2010). Manajemen Perbankan: Dari Teori Menuju Aplikasi (Edisi Pert). KENCANA.

Jalaludin, E. (2021). Mempertahankan Kinerja Karyawan Di Tengah Pandemi Covid-19. 14(1), 131-152.

Juliana, S., \& Ade Sofyan Mulazid. (2017). Analisa Pengaruh BOPO, Kecukupan Modal, Pembiayaan Bermasalah, Bagi Hasil dan Profitabilitas Terhadap Simpanan Mudharabah Pada Bank Umum Syariah Periode 2011-2015. Jurnal Ekonomi Dan Bisnis Islam, 2, 2545.

Monulandi, M. M., Dumais, J. N. K., \& Pangemanan, L. R. J. (2016). Persepsi Nasabah Terhadap Penerapan Prinsip 5C Dalam Penyaluran Kredit Usaha Rakyat (KUR) Oleh PT. Bank Rakyat Indonesia (Persero) Tbk Unit Tombat, Minahasa Tenggara. 12, 303-314.

Niken Widya Yunita. (2020, March). Penyebab, Asal Mula, dan Pencegahan Virus Corona di Indonesia. In detikNews. https://news.detik.com/berita/d-4956764/penyebab-asalmula-dan-pencegahan-virus-corona-di-indonesia

Nursyahriana, A., Hadjat, M., \& Tricahyadinata, I. (2017). Analisis Faktor Penyebab Terjadinya Kredit Macet. 19(1), 1-14.

Pandi Afandi. (2010). Analisis Implementasi 5C Bank BPR Dalam Menentukan Kelayakan Pemberian Kredit Pada Nasabah (Studi Kasus Pada PD BPR Salatiga dan PT BPR Kridaharta Salatiga). 3, 55-69.

Saraswati, R. A. (2012). Peranan Analisis Laporan Keuangan, Penilaian Prinsip 5C Calon Debitur dan Pengawasan Terhadap Efektivitas Pemberian Kredit Pada PD BPR Bank Pasar Kabupaten Temanggung. Jurnal Nominal, I(5).

Slamet Riyanto, \& Aglis Andhita Hatmawan. (2020). Metode Riset Penelitian Kuantitatif (Penelitian di Bidang Manajemen Teknik, Pendidikan dan Eksperimen). CV. Budi Utama.

Sudarto, A. (2020). Penyelesaian Pembiayaan Bermasalah Pada Lembaga Keuangan Syriah 
Etihad: Journal of Islamic Banking and Finance

Vol. 1, No. 2 Juli-Desember 2021: 98-114

Studi BMT Al Hasanah Lampung Timur. 5(Mei 2017), 99-116.

Sumadi. (2020). Menakar Dampak Fenomena Pandemi Covid-19 Terhadap Perbankan Syariah. Hukum Ekonomi Syariah, 3(2), 145-162.

Thorik, S. H. (2020). Efektivitas Pembatasan Sosial Berskala Besar Di Indonesia Dalam Penanggulangan Pandemi Covid-19. Jurnal Adalah : Buletin Hukum Dan Keadilan, 4(1), 115-120.

Ulfa. (2017). Pengaruh Faktor Internal Debitur Terhadap Kredit Bermasalah Pada PT. Bank Negara Indonesia (Persero) Tbk Cabang Palu. Katalogis, 5 Nomor 9, 45-54. 